\title{
ELECTRORETINOGRAPHICALLY-DETERMINED SCOTOPIC SPECTRAL SENSITIVITIES OF SOME MARINE FISH
}

\author{
S. S. EASTER, JR. and D. I. HAMASAKI \\ Department of Zoology, University of Michigan, Ann Arbor, Michigan 48104; Bascom Palmer Eye \\ Institute, University of Miami Medical School, 1638 N.W. Tenth Avenue, Miami, Florida 33152
}

(Received 27 July 1972)

\section{INTRODUCTION}

BotH BURKHARDT (1966) and WrTKovsKY (1968) used the electroretinogram to determine the dark-adapted spectral sensitivity of the goldfish and carp, respectively. They found that the $b$-wave was much more sensitive to long wavelengths than one would predict from the absorption spectrum of carp porphyropsin (Crescrtelli and DarTnall, 1954). They suggested that the cones were responsible for this heightened red-sensitivity, since two of the three classes of cones peak at longer wavelengths than the rod pigment (MARKs, 1963, 1965; LIEBMAN and ENTINE, 1964). WITKOVSKY (1967) had shown that the spectral sensitivity of dark-adapted carp retinal ganglion cells matched porphyropsin, but with thresholds lower than the $b$-wave by 2 to $3 \log$ units. Apparently, the rod-mediated ERG was so weak a signal that intensities needed to evoke it also stimulated the cones, thus making the $b$-wave an unreliable indicator of scotopic activity.

This is different from other mixed retinas. In dark-adapted human eyes, for instance, the $b$-wave spectral sensitivity (RIGGs, BERRY and WAYNER, 1949) closely matches the absorption spectrum of human thodopsin (Crescitrlul and DarTnall, 1953). Thus the human $b$-wave is a good indicator of scotopic function.

The work reported below was undertaken in order to learn if the fish electroretinogram generally is an unreliable indicator of rod function. We conclude that it is not. In the species we studied, all with duplex retinas, the dark-adapted spectral sensitivities closely matched the pigment template of DARTNALL (1953).

\section{METHODS}

The fish were all caught either in Biscayne Bay or in the reefs off the Florida Keys by the collecting boats of the Miami Seaquarium. They were kept in aerated sea water for a day or two before the experiments were carried out. Three species were used: Lutjanus griseus, the gray snapper, often called the mangrove snapper; Haemulon flavolineatum, the blue-striped grunt; and Epinephelus striatus, the Nassau grouper. All three are common to the reefs around southern Florida. Their weights ranged from 100 to $400 \mathrm{~g}$.

The preparation went as follows. First, an intramuscular injection of $d$-tubocurarine $2-5 \mathrm{mg} / \mathrm{kg}$ body wt., paralyzed the fish. Then it was clamped about the body, and its mouth fitted around an inlet tube through which aerated sea water flowed at $100-200 \mathrm{ml} / \mathrm{min}$ to irrigate the gills. The fluid was recycled continually.

The animal was surrounded by a Faraday cage. Both eyes were out of the water. The active electrode was a cotton wick positioned on the right cornea, and connected via a saline-agar bridge to a silver wire. The right cornea and lens remained clear for the duration of the experiments, often $12 \mathrm{~h}$. Usually, the left eye developed corneal and/or lenticular opacities, presumably because it lacked the moist wick of the active electrode. The indifferent electrode was a needle inserted subdermally into the head. An alligator clip attached to the fish's tail grounded the preparation. The two electrodes went to a differential amplifier which passed $0.2-250 \mathrm{~Hz}$, and had a gain of 10,000. The amplified signals were displayed on an oscilloscope and accumulated on a signal averager (Computer of Average Transients $900 \mathrm{C}$, Technical Instruments, Inc.). 
The averager is linear over the range $\pm 3 \mathrm{~V}$; the amplified ERG input characteristically varied between $\pm 2 \mathrm{~V}( \pm 200 \mu \mathrm{V}$ at the input $)$.

A dual beam stimulator provided both stimuli and adapting lights from the same source, a $150 \mathrm{~W}$ xenon arc lamp driven by a regulated power supply (George Gates and Company). Both beams were collimated separately and the spectral content of each was controlled by interference filters (Oriel Optics) of $10 \mathrm{~nm}$ half bandwidth, spaced at $20 \mathrm{~nm}$ intervals from 420 to $660 \mathrm{~nm}$. Intensity was controlled by metal film neutral density filters (Laser Energy, Inc.). The beams were joined in a combining cube and entered the animal's Faraday cage through a small opening. Then the beams were deflected by front surface mirrors either onto the animal's right pupil directly or onto a diffuser, a fragment of a ping-pong ball, positioned $0.5 \mathrm{~cm}$ before the pupil. The image of the test spot on the diffuser was a square, $0.5 \mathrm{~cm}$ on a side. The adapting spot was a rectangle, $1.5 \times 0.6 \mathrm{~cm}$.

The spectral energy of the beam was measured with a thermopile (Reeder Model FSL-12C) positioned at the site of the cornea, with and without the diffuser in place. The maximal quantal flux was at $560 \mathrm{~nm}$ $\left(1.3 \times 10^{13}\right.$ quanta $\left./ \mathrm{cm}^{2} \mathrm{sec}\right)$.

The experimental procedure went as follows. Immediately after the animal was positioned, and the baseline was seen to be stable, the Faraday cage was shielded with opaque cloths, and the fish allowed to dark adapt for 1-2 hr. Then, the spectral sensitivity was determined conventionally, using stimuli of greater than one second duration and calling "threshold" the intensity which evoked a $20-30 \mu \mathrm{V} b$-wave in response to a single flash. Then a more precise determination was made, with the signal averager. In this procedure, the beam was chopped once per second, and the sweep of the signal averager was trigeered synchronously. Depending upon how noisy the base line was on any particular day, either 10 or 30 sweeps were summed for each wave length-intensity combination. An average response of $10 \mu \mathrm{V}$ was usually used as criterion. For each wavelength, several neutral density filters were interposed to evoke responses which bracketed the criterion. These filters differed by $0.2,0.3$ or $0.5 \log$ units. The log threshold was determined by linear interpolation and corrected for quantal flux.

\section{RESULTS}

Qualitative examination of the responses suggested that there was only a single mechanism operative in the dark adapted retina. Figure 1 illustrates this point by a comparison of individual records of sub-and supra-threshold ERG's obtained from one dark-adapted fish, in response to stimuli of three different wavelengths, 420, 520 and $640 \mathrm{~nm}$. Quite clearly, the waveforms do not differ appreciably from one another as they might if more than one spectral mechanism were operative.

The threshold response determined by inspection of single sweeps would, in most cases, be about the second sweep from the bottom in each family of traces. The threshold response of $10 \mu \mathrm{V}$, determined by averaging many sweeps and interpolating, lay between the intensities which evoked the two lowest traces. These two intensities differed by only $0.5 \log$ units, so the "averaged" thresholds in this report can be no more than $0.5 \log$ unit lower than the thresholds determined by single sweeps.

The most data were obtained on Lutjanus griseus, the gray snapper. The open circles of Fig. 2 show the spectral sensitivity to $1 \mathrm{~Hz}$ flicker, in the dark, averaged from results on five fish. The data were pooled as follows. Once the log quantum spectral sensitivity for a fish was determined, the value at $520 \mathrm{~nm}$ was set to 0.00 relative $\log$ units, and all others expressed relative to it. These relative log thresholds were averaged, and the antilog of the mean appears in Fig. 2. Note that the abscissa is expressed in wave numbers (1/wavelength), the appropriate metric for fitting spectral sensitivity to Dartnall's photopigment template (DARTNALL, 1953). The solid curve is the extinction spectrum of a pigment with its maximum at $1.95 \times 10^{6} \mathrm{~m}^{-1}$ (513 nm wavelength). This position was chosen for best fit to the data, and the fit is quite good, in contrast with the poor fit the porphyropsin curve made with goldfish and carp scotopic action spectra in the reports mentioned earlier (BURKHARDT, 1966; WrTkovsky, 1968).

One possible reason for the difference between these results and the earlier ones would be an all-rod retina in the snapper. This possibility was ruled out by determining that the 

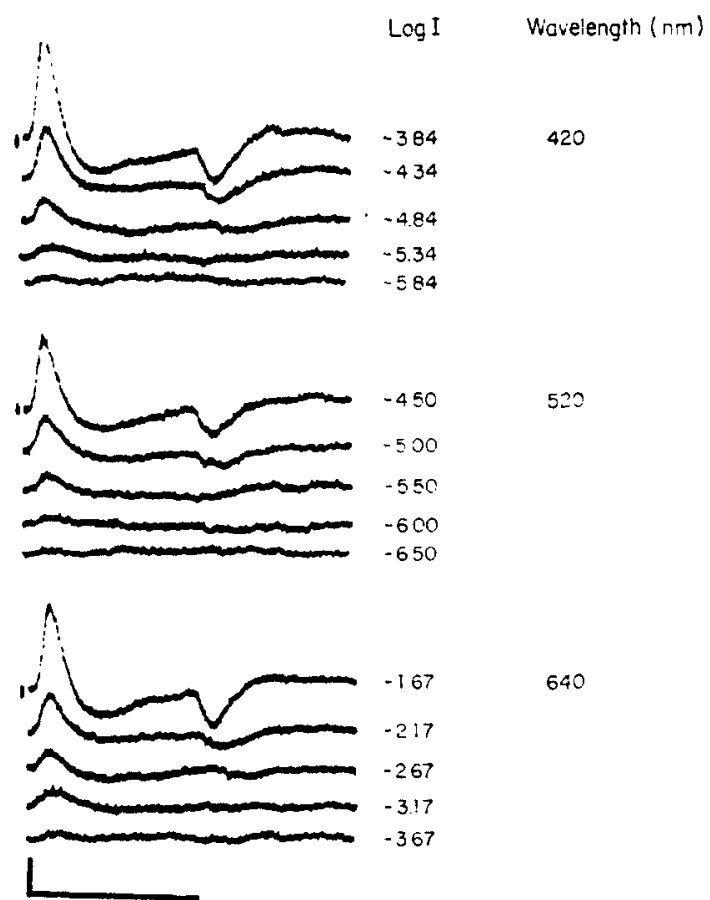

640

Fig. 1. Each family of traces was obtained with one wavelength (right column) and a range of intensities (central column). The intensities are expressed as $\log _{10}$ (quantal flux) relative to the maximum flux available at $560 \mathrm{~nm}$. All data were obtained within a few minutes from one dark adapted Lutjanus griseus. Calibration: $25 \mu \mathrm{V}$ (vertical), $0.5 \mathrm{sec}$ (horizontal).

light-adapted spectral sensitivity was different from that in the dark. The filled circles show the values (relative to $560 \mathrm{~nm}$ ) obtained when the test light flickered at $20 / \mathrm{sec}$ and was superimposed on a white background four log units above the animal's dark-adapted threshold. Similar, but not identical, approaches were used with other animals to uncover a photopic spectral sensitivity, and always the results were as shown here, a shift to greater sensitivity at long wavelengths. However, there appeared to be no single photopic mechanism, as the shape of the action spectrum depended on the flicker rate and the intensity and spectral content of the background field. These differences were not studied in detail, but one may conclude that a different spectral sensitivity, more sensitive to long wavelengths, applies under photopic conditions.

Similar results were obtained with the other species of fish. The open circles of Fig. 3 represent means of five data sets obtained from three Haemulon. Three of the data sets were obtained in total darkness, two on very dim backgrounds which raised the threshold by 0.5 and $1.5 \log$ units. All five data sets were so similar that pooling them was justified. As in Fig. 2, the curve is a Dartnall template pigment, here with its maximum at $518 \mathrm{~nm}$, and the data fit it quite well. The filled circles show the spectral sensitivity to $20 / \mathrm{sec}$ flicker superimposed on a white background field $3.5 \mathrm{log}$ units above absolute threshold. They are obviously related to another, more long wavelength-sensitive system, establishing that this is also a duplex retina. 


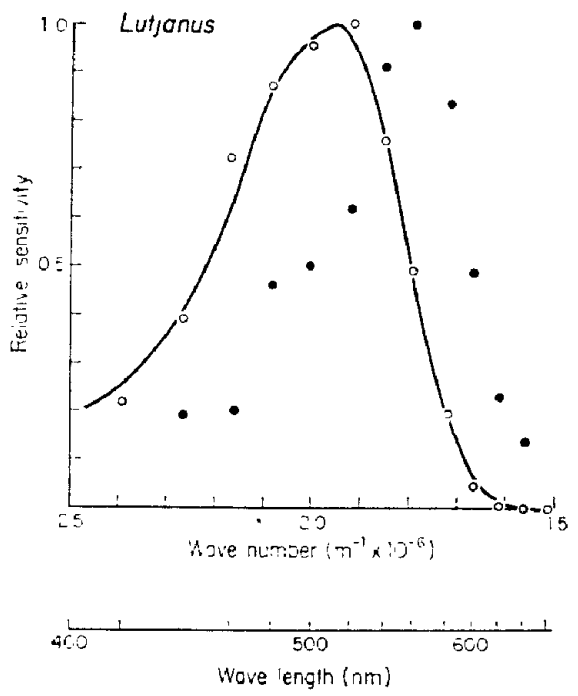

FIG. 2. Spectral sensitivities of Lutjanus griseus. The abscissa gives wave number (1/wavelength) of the stimulus light. The ordinate gives the reciprocal of the threshold, the quantum flux necessary to evoke the criterion response. For the dark-adapted values (open circles) the threshold at $1.92 \times 10^{6} \mathrm{~m}^{-1}(520 \mathrm{~nm}$ wavelength) was arbitrarily set at unity and all others expressed relative to it. The light-adapted data (filled circles) are normalized relative to the threshold at $560 \mathrm{~nm}$. The curve is the extinction spectrum of a vitamin $A_{1}$-based visual pigment (DARTNALL, 1953) with maximum sensitivity at $1.95 \times 10^{-6} \mathrm{~m}^{-1}(513 \mathrm{~nm}$ wavelength). The open circles show the dark adapted values to $1 \mathrm{~Hz}$ flicker, averaged from five fish. The filled circles show the results from a single tsh exposed to $20 \mathrm{~Hz}$ flicker on a white background. The criterion responses were a $10 \mu \mathrm{V} b$-wave (open circles) and a $20 \mu \mathrm{V}$ peak-to-peak response (filled circles).

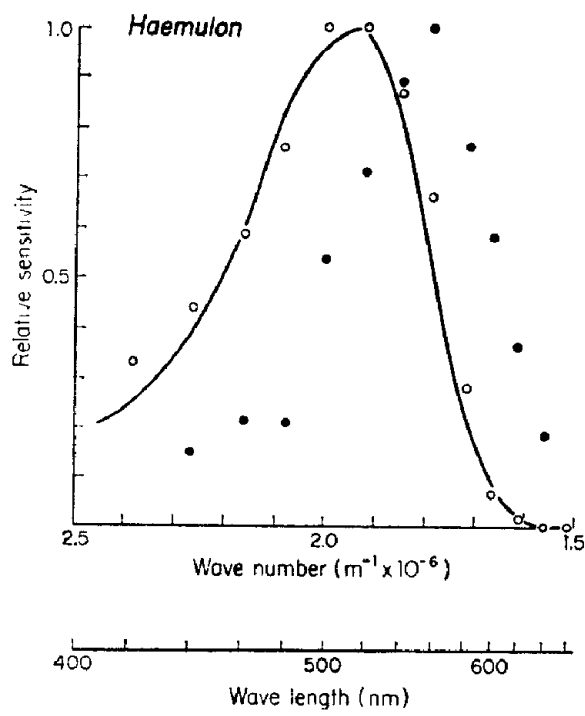

FIG. 3. Spectral sensitivities of Haemulon favolineatum. The curve peaks at $1.93 \times 10^{6} \mathrm{~m}^{-1} 1(518$ $\mathrm{nm})$, The conventions are the same as in Fig. 2. 
Finally, Fig. 4 contains data obtained from a single Epinephelus, with the same results as the other two graphs; namely, that the dark-adapted spectral sensitivity fits a single Dartnall template pigment, but higher backgrounds and rapidly flickering light bring out a photopic mechanism.

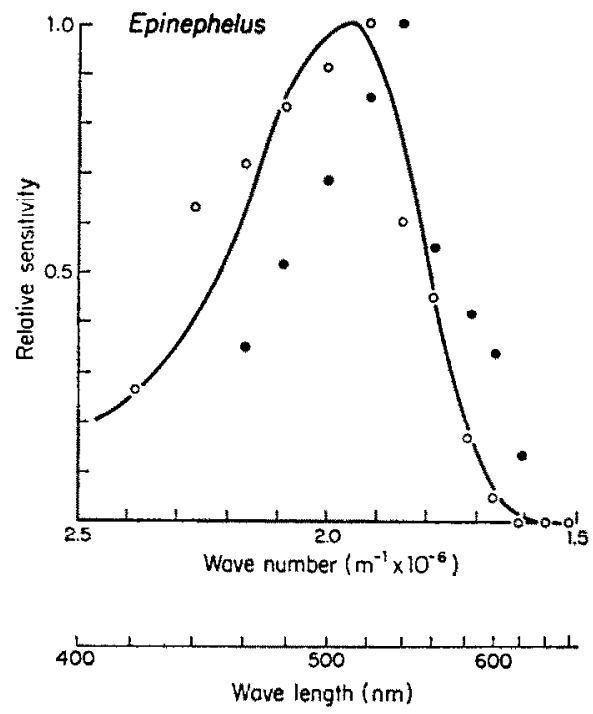

Fic. 4. Spectral sensitivities of Epinephelus striatus. The curve peaks at $1.95 \times 10^{6} \mathrm{~m}^{-1}(513$ $\mathrm{nm})$. The conventions are the same as in Fig. 2.

\section{DISCUSSION}

These results show that in some teleosts, the $b$-wave may be a reliable indicator of rod vision, even at long wavelengths. The contamination of the scotopic spectral sensitivity by cones, observed by BURKHARDT (1966) and WrTKOvSKY $(1967,1968)$ probably results from the relatively high cone/rod ratios in the fish they studied. WUNDER (1925) determined these ratios in 24 species of fish and found that the carp (Cyprinus carpio), the same species studied by Witkovsky, had a cone/rod ratio of $12 / 38$, while the crucian carp (Carassius vulgaris), of the same genus as the goldfish (Carassius auratus) studied by Burkhardt, showed a ratio of 7/32. Both of these ratios are high on a scale which ranged from 15/29 (Tinca vulgaris) down to $3 / 260$ (Lota vulgaris). In carp, the relatively low density of rods probably accounts for the insensitivity of the scotopic $b$-wave, since it reflects summated activity of the entire retina and sheer numbers of cells will play an important role in the size of the signal. This tentative explanation is supported by Dowling and RIPPS (1970), who found that in the all-rod retina of the skate, the ganglion cells were only one log unit more sensitive than the $b$-wave, rather than 2-3 log units, as in carp (WITKovsKY, 1967).

The three marine teleosts studied here probably represent intermediate cases in which cones are present, but in lower proportions than in goldfish and carp. For this reason, the signals due to activity in the rods are not masked, and can be reliably monitored by the $b$-wave, even at long wavelengths. 
Acknowledgements-These experiments were supported by research grants to S. S. E. from the National Institutes of Health (EY-00168) and the Office of Research Administration of the University of Michigan, and by a grant to D. I. H. from the National Institutes of Health (EY-00376). D. I. H. held a Career Development Award from the U.S. Public Health Service. We thank Mr. W. ZenER of the Miami Seaquarium for supplying the fish, and Mr. O. NAVARRo for technical assistance.

\section{REFERENCES}

BuRKHARDT, D. A. (1966). The goldfish electroretinogram: relation between photopic spectral sensitivity functions and cone absorption spectra. Vision Res. 6, 517-532.

Crescrtelli, F. and Dartnall, H. J. A. (1953). Human visual purple. Nature, Lond. 172, 195-196.

Crescitelli, F. and Dartnall, H. J. A. (1954). A photosensitive pigment of the carp retina. J. Physiol., Lond. 125, 607-627.

DarTnall, H. J. A. (1953). The interpretation of spectral sensitivity curves. Br. Med. Bull. 9, 24-30.

DowLING, J. E. and RIPPS, H. (1970). Visual adaptation in the retina of the skate. J. gen. Physiol. 56, 491-520.

LIEBMAN, P. S. and ENrINE, G. (1964). Sensitive/ low-light level microspectrophotometer: detection of photosensitive pigments of retinal cones. J. opt. Soc. Am. 54, 1451-1459.

MarKs, W. B. (1963). Difference spectra of visual pigments in single goldfish cones. Ph.D. Dissertation, Johns Hopkins University.

Marks, W. B. (1965). Visual pigments of singie goldfish cones. J. Physiol., Lond. 178, 14-32.

Rigos, L. A., BERRY, R. N. and WAYNER, M. (1949). A comparison of electrical and psychophysical determinations of the spectral sensitivity of the human eye. J. opt. Soc. Am. 39, 427-436.

Wrrkovsky, P. (1967). A comparison of ganglion cell and $S$-potential response properties in carp retina. J. Neurophysiol. 30, 546-561.

WrTkovsky, P. (1968). The effect of chromatic adaptation on color sensitivity in the carp electroretinogram. Vision Res. 8, 823-837.

WUNDER, W. (1925). Physiologische und vergleichend-anatomische Untersuchungen an der Knochenfischnetzhaut. Z. vergl. Physiol. 3, 1-61.

Abetract-The $b$-wave threshold spectral sensitivity was determined in three species of marine fish. In all cases, the action spectrum of the dark adapted animal peaked at $510-520 \mathrm{~nm}$ and fit Dartnall's template curve for the extinction spectrum of a vitamin $A_{1}$-based visual pigment. High frequency flicker of the stimulus on a white background revealed a long-wavelengthsensitive photopic mechanism, establishing that these were duplex retinas. We conclude that in these teleosts, the dark adapted b-wave is a reliable indicator of rod function, in marked distinction to the case with goldfish and carp.

Rémiń-On détermine sur trois especes de poissons de mer la sensibilité spectrale par le seuil de l'onde $b$. Dans tous les cas le spectre d'action de l'animal adapté à l'obacurité a son maximum entre $510-520 \mathrm{~nm}$ et obeit au nomogramme de Dartnall pour le spectre d'extinction d'un pirment à base de vitamine $A_{1}$. Le papillotement à haute fréquence du stimulus sur fond blanc révele un mócanisme photopique sensible aux grandes longueurs d'onde, établissant la dualité rétinienne. Chez ces téléstéens, l'onde $b$ en adaptation à l'obscurité est donc un bon indicateur de la fonction des bâtonnets, à l'opposé des cas du cyprin doré et de la carpe.

Zneamananano-Die spektrale Empfindlichkeit der $b$-Wellen-Schwelle wurde bei drei Seefischarten bestimmt. In allen Fallen stieg das Aktionsspektrum des dunkel-adaptierten Tieres bei $510-520 \mathrm{~nm}$ steil an und passte sich der Dartnall'schen Grundkurve fur das Extinktionsspektrum eines Sehstoffes auf Vitamin $A_{1}$-Basis an. Hochfrequentes Flimmern des Testreizes auf einem weiseen Hintergrund offenbarte einen auf lange Wellenllingen ansprechenden photopischen Mechanismus, der im betrefienden Fall das Vorhandensein von zwei Netzhauten bestltigte. Wir schliessen daraus, dass bei diesen Teloosten die dunkel-adaptierte $b$-Wolle ein zuverlissiger Indikator der Stabchenfunktion ist-in deutlichem Unterschied zum Fall des Goldfischs und des Karpfens. 
Резюме-Пороговая спектральная чувствительность была определена с помощью волны-"в" злектроретинограммы у трех видов морских рыб. Во всех случаях, спектр ден̆ствия темноадаттированного животного имел махсимум на 510-520 нм и совпадал со стандартно хриво Dartnall, для спектра поглощения зрительного пштмевта, в основе которого находится витамин $\mathbf{A}_{1}$, Стимул, мелькаюший с высокой частотой на белом фоне, обнарухсивает, чувствнтельный х длинным волнам спектра, фототически механизм. это указывает на то, что псследуемые сетчатки обладают фунхиновальной и морфологической двойственностью.

Делается заключение, что у этих костистых рыб, “в"'-волна является адекватным пндахатором функиия палочек, в это значительно отличается от того, что нмеется у золотой рыбки в харпа. 